\title{
Protein identification and in vitro digestion of fractions from Tenebrio molitor
}

\author{
Liya $\mathrm{Yi}^{1} \cdot$ Martinus A. J. S. Van Boekel $^{1} \cdot$ Sjef Boeren $^{2} \cdot$ Catriona M. M. Lakemond $^{1}$
}

Received: 8 October 2015 / Revised: 20 December 2015 / Accepted: 24 December 2015 / Published online: 16 January 2016

(C) The Author(s) 2016. This article is published with open access at Springerlink.com

\begin{abstract}
The nutritional value of insect protein is evaluated not only in amino acid composition, but also in protein digestibility. The general amino acid composition of Tenebrio molitor has been reported before, but limited knowledge is available on its digestibility. The objective of this study was to investigate in vitro protein digestibility of whole T. molitor larvae, a water-soluble fraction (supernatant) and water-insoluble fractions (pellet and residue), and to identify which proteins were present in the fractions studied. The digestibility of the supernatant fraction $(\sim 80 \%)$ was much higher than that of pellet $(\sim 50 \%)$ and residue $(\sim 24 \%)$ after in vitro gastroduodenal digestion as was determined using the $o$-phthaldialdehyde (OPA) method. More proteins were digested after pepsin/ pancreatin digestion than after only pepsin digestion. The most abundant proteins in the supernatant were hemolymph protein $(\sim 12 \mathrm{kDa})$, alpha-amylase $(\sim 50 \mathrm{kDa}$, a putative allergen), and muscle proteins (e.g. actin $30-50 \mathrm{kDa}$ )
\end{abstract}

Electronic supplementary material The online version of this article (doi:10.1007/s00217-015-2632-6) contains supplementary material, which is available to authorized users.

Liya Yi

yiliya003@gmail.com; liya.yi@wur.nl

$\triangle$ Catriona M. M. Lakemond

catriona.lakemond@wur.nl

Martinus A. J. S. Van Boekel

tiny.vanBoekel@wur.nl

Sjef Boeren

sjef.boeren@wur.nl

$1 \quad$ Food Quality and Design, Wageningen University and Research Centre, Wageningen, The Netherlands

2 Laboratory of Biochemistry, Wageningen University and Research Centre, Wageningen, The Netherlands in the pellet fraction as determined from LC-MS/MS and SDS-PAGE. In conclusion, the proteins in the soluble fraction that contained hemolymph proteins were more easily digestible than the insoluble, muscle protein-containing fractions.

Keywords Insect protein - Tenebrio molitor $\cdot$ In vitro digestion $\cdot$ Protein identification $\cdot$ LC-MS/MS

\section{Introduction}

The Yellow mealworm (Tenebrio molitor) of the order Coleoptera is currently reared as fish bait or as feed for fish, amphibians, reptiles, turtles, birds, fowls, and small mammals kept as household pets or in zoos [1]. The protein content of the Yellow mealworm ranged from 24.3 to $27.6 \%$ in fresh insects (63-69\% in dry matter), which is comparable to conventional meat protein sources (about 15-22 \%) [13]. In studies on protein quality, Yi et al. [4] reported that the Yellow mealworm contains all the essential amino acids needed for human nutrition.

However, the nutritional value of a food protein is evaluated not only by its amino acid composition, but also by protein digestibility. Protein digestion in humans generally starts with pepsin cleavage in the stomach, subsequently trypsin and chymotrypsin digestion in the intestinal lumen, and the last step includes cleavage by proteases present on the intestinal surface [5]. In vitro digestion is often used as an approximation for in vivo processes [6]. The major advantage of an in vitro method is that the procedure of digestion is relatively simple and rapid in comparison with in vivo digestion. However, in vitro methods cannot mimic completely real $\mathrm{pH}$ and temperature conditions in the digestive system. Furthermore, in vitro experiments often 
give lower protein digestibility values than in vivo studies [7].

During protein digestion and absorption in the human body, protein is broken down to amino acids and peptides by digestive enzymes [5]. Afterward, free amino acids and small peptides are absorbed through the gastrointestinal wall. The extent of protein hydrolysis can be evaluated by measuring the degree of hydrolysis (DH). The DH is defined as the percentage of the total number of peptide bonds in a protein that have been cleaved during hydrolysis [8]. Several methods to measure protein hydrolysis were reviewed by Rutherfurd [8]: (1) determining the amount of nitrogen released during hydrolysis (after precipitation by acids like trichloroacetic acid) by the Kjeldahl method; (2) quantifying the amount of free amino groups released during hydrolysis by formol titration; (3) measuring compounds that react specifically with amino groups such as trinitrobenzenesulfonic acid (TNBS), o-phthaldialdehyde (OPA), and ninhydrin [8]; (4) determining the protons released during hydrolysis by titration to calculate the DH (pH stat method) [9]. Nielsen et al. [10] and Schasteen et al. [11] stated that prediction of amino acid digestibility of food proteins in vitro assays by using $o$-phthaldialdehyde (OPA) is more rapid and accurate when compared to other methods. However, the reaction between cysteine and OPA reagent is weak and unstable, which could lead to underestimation of protein hydrolysis [9].

There is no literature on protein digestibility of $T$. molitor as a whole or on its extracted protein fractions. However, protein digestibility of other edible insects has been reported. Protein digestibility of eri silkworm (Samia ricinii) pupae was about $87 \%$ determined via the Kjeldahl method using a nitrogen factor of 6.25 mentioned by Longvah et al. [12] as tested on rats by in vivo digestion. Furthermore, protein digestibility via in vitro methods using pepsin-pancreatin was found to be around $91 \%$ in fresh termites of the species Macrotermes subhylanus and $82-86 \%$ in the grasshopper Ruspolia differens, as determined by TCA-nitrogen content. The values obtained were comparable to the values reported of conventional animal sources ( $89 \%$ for whole beef, $90 \%$ for pork, $78 \%$ for turkey, and $85 \%$ for salmon) [13]. According to Ramos-Elorduy et al. [14], protein digestibility of 21 selected types of edible insect species in Mexico was found to be 60-98\% based on nitrogen content analyzed after in vitro digestion.

The studies that deal with protein digestibility of insects do not give any information on the types of proteins that are digested. The reason for this is that very limited knowledge exists on which bulk proteins are present in insects [15]. Mass-spectrometry-based methods can be used for protein identification. Often tryptic digestion of proteins into peptides is performed as a pre-treatment since peptides can be identified more easily and at a much higher sensitivity than proteins. A strength of tandem mass spectrometry is the inherent ability to sequence peptides directly from mixtures [16].

Yi et al. [4] extracted one water-soluble protein fraction (supernatant) and two water-insoluble protein fractions (pellet and residue) from T. molitor using an aqueous extraction method. In that study, the fractions were characterized in terms of protein content and molecular weight by SDS-PAGE. The objective of the present study was to identify proteins using LC-MS/MS and investigate protein digestibility (in vitro) of the ground whole insect and its fractions (supernatant, pellet, and residue) obtained by aqueous extraction according to Yi et al. [4].

\section{Materials and methods}

\section{Materials}

Tenebrio molitor larvae were purchased from a commercial supplier (Kreca V.O.F, Ermelo, The Netherlands). The insects were sieved to get rid of feed, and then killed by immersing them into liquid nitrogen before processing.

\section{Preparation of tested protein fractions}

Frozen insects were ground, freeze-dried, and defatted as described by Yi et al. [4]. The proximate composition of T. molitor was determined after processing. Defatted $T$. molitor meal of the whole larvae was stored at $-20{ }^{\circ} \mathrm{C}$.

Water-soluble and water-insoluble protein fractions were obtained by an aqueous extraction according to Yi et al. [4]. In short, $1200 \mathrm{~mL}$ demineralized water with $2 \mathrm{~g}$ ascorbic acid was added to $400 \mathrm{~g}$ of $\mathrm{N}_{2}$-frozen insects. After blending for $1 \mathrm{~min}$, the obtained insect suspension was sieved through a stainless steel filter sieve with a pore size of $500 \mu \mathrm{m}$. The filtrates and residues were collected. The filtrate was centrifuged to yield a supernatant, a pellet, and fat fraction. The fat fraction was discarded. Three protein fractions were thus obtained: a supernatant (water-soluble protein fraction), a pellet (water-insoluble protein fraction), and a residue (water-insoluble protein fraction). After freeze-drying all fractions, pellet and residue fractions were defatted by hexane extraction (Biosolve, CAS nr. 110-54-3) in a Soxhlet apparatus for $6 \mathrm{~h}$. Subsequently, protein content was determined by Dumas as mentioned by Yi et al. [4]. The proximate composition (including fat and protein content) of water-soluble and water-insoluble protein fractions was determined after the above-mentioned processing. The extraction procedure was performed in duplicate starting twice with a new insect batch. 


\section{Filter-aided sample preparation (FASP)}

FASP was used to prepare protein samples from the three protein fractions obtained as described by $\mathrm{Lu}$ et al. [17]; Wisniewski et al. [18] with some modifications. The pellet fractions were washed twice with water to remove soluble protein in pellet fractions before FASP. Peptide measurements were taken by nanoLC-LTQ-Orbitrap XL-MS/ MS (Thermo Electron, San Jose, CA, USA) as described by Lu et al. [17]. Results from LC-MS/MS were searched by MaxQuant 1.3.0.5 as described by Cox and Mann [19], using default settings for the Andromeda search engine by Cox et al. [20] except that extra variable modifications were set for de-amidation of $\mathrm{N}$ and $\mathrm{Q}$.

An insecta database including proteins of T. molitor was downloaded from UniProt on July 1, 2014 (taxonomy 50,557, database size: 1,070,041 sequences). This database was used together with a contaminant database that contains sequences of common contaminants (59 sequences) as for instance: BSA (P02769, bovin serum albumin precursor), Trypsin (P00760, bovin), Trypsin (P00761, porcin), Keratin K22E (P35908, human), Keratin K1C9 (P35527, human), Keratin K2C1 (P04264, human), and Keratin $\mathrm{K} 1 \mathrm{CI}$ (P35527, human). The "label-free quantification" as well as the "match between runs" (set to 2 min) options were enabled. De-amidated peptides were allowed to be used for protein quantification, and all other quantification settings were kept default.

Extra filtering and further bioinformatic analysis of the MaxQuant/Andromeda workflow output and the analysis of the abundances of the identified proteins were performed with the Perseus 1.3.0.4 module (available at the MaxQuant suite) as described before by Smaczniak et al. [21]. The proteomics result contained peptides and proteins with a false discovery rate (FDR) of less than $1 \%$ and proteins with at least two identified peptides of which at least one should be unique and at least one should be unmodified without any reversed hits.

Total non-normalized protein intensities corrected for the number of measurable tryptic peptides [intensity-based absolute quantitation (iBAQ)] were, after taking the normal logarithm, used for further data analysis [22]. These "size-corrected" iBAQ intensities are related to the protein concentration in the sample. The key words "myosin, actin, sarcoplasmic, troponin" were used for searching muscle proteins. In addition, family and domain databases (including InterPro, Pfam and PRINTS) were used for searching on most relevant proteins to better describe putative uncharacterized proteins. A threshold of $\log 10$ (iBAQ) $>7$ was used to select the most abundant non-muscle proteins for all fractions.

To confirm a high sequence identity for non-T. molitor proteins that were identified as either actin, tropomyosin 1 , or tropomyosin 2, an alignment was made with the Clustal $\mathrm{O}$ multiple sequence alignment tool on the UniProt Web site. All actin, tropomyosin 1, and tropomyosin 2 sequences are shown grouped in Table 2 together with their highest iBAQ values obtained for one of the sequences.

\section{In vitro digestion of proteins}

Gastric-duodenal digestion of protein fractions from $T$. molitor was simulated by using the method of Vreeburg et al. [23] as a basis. The water-soluble/water-insoluble protein fraction $(4.5 \mathrm{~g})$ was suspended in $30 \mathrm{~mL}$ Millipore water containing $140 \mathrm{mM}$ sodium chloride (Merck, CAS nr. 7647-14-5) and $5 \mathrm{mM}$ potassium chloride (Merck CAS nr. 7447-40-7), and vortexed $5 \mathrm{~min}$ for homogenizing the samples. The $\mathrm{pH}$ was adjusted to 2 with $1 \mathrm{M} \mathrm{HCl}$ (Merck, CAS nr. 7647-01-0). Six grams of the mixture was incubated with $0.667 \mathrm{~mL}$ of $40 \mathrm{mg} / \mathrm{mL}$ pepsin (Sigma-Aldrich, CAS nr. 9001-75-6, 3200-4500 units/mg protein) in $\mathrm{HCl}$ $(0.1 \mathrm{M})$ during $0,10,20,30,60$, and $120 \mathrm{~min}$ at $37{ }^{\circ} \mathrm{C}$ while shaking. The reaction was stopped by adjusting to pH 5.8 using a solution of $1 \mathrm{M} \mathrm{NaHCO}_{3}$ (Merck, CAS nr. 144-55-8). The mixture was called simulated gastric fluid (SGF). After centrifugation $\left(3200 \mathrm{~g}, 4{ }^{\circ} \mathrm{C}\right.$ for $\left.30 \mathrm{~min}\right)$, the supernatant was stored as gastric digestible protein fractions (GDP). The experiment was performed in duplicate.

Subsequently, three grams of SGF was added to $0.95 \mathrm{~mL}$ of $4 \mathrm{mg} / \mathrm{mL}$ pancreatin from porcine pancreas (SigmaAldrich CAS nr. 8049-47-6) in $0.1 \mathrm{M} \mathrm{NaHCO}_{3}$, and $0.5 \mathrm{~mL}$ of a mixture of $94.6 \mathrm{mg} / \mathrm{mL}$ taurocholic acid sodium salt hydrate (Sigma-Aldrich CAS nr. 345909-26-4) and $83 \mathrm{mg} /$ $\mathrm{mL}$ sodium glycodeoxycholate (Sigma-Aldrich CAS nr. 16409-34-0) in $0.1 \mathrm{M} \mathrm{NaHCO}_{3}$. The $\mathrm{pH}$ was adjusted to 6.5 with $1 \mathrm{M} \mathrm{NaHCO}_{3}$, and the headspace was flushed with nitrogen gas. Next, the mixture was incubated in a $37{ }^{\circ} \mathrm{C}$ water bath, while shaking for $2 \mathrm{~h}$. After centrifugation $\left(3200 \mathrm{~g}, 4{ }^{\circ} \mathrm{C}\right.$ for $\left.30 \mathrm{~min}\right)$, this supernatant is further referred to as duodenal digestible protein fraction (DDP). The experiment was performed in duplicate.

\section{Protein digestion quantification}

Free $\alpha$-amino groups were determined after reaction with $o$-phthaldialdehyde (OPA), following the method of Nielsen et al. [10]. An amount of $200 \mathrm{~mL}$ OPA reagent was prepared by using $7.62 \mathrm{~g}$ of sodium tetraborate (Boraxdecahydrate) (Sigma-Aldrich CAS nr. 1303-96-4) and $200 \mathrm{mg}$ of sodium dodecyl sulfate (SDS) (Sigma-Aldrich CAS nr. 151-21-3) in $150 \mathrm{~mL}$ deionized water. Besides that, $160 \mathrm{mg}$ OPA was dissolved in $4 \mathrm{~mL}$ ethanol (Merck CAS nr. 64-175) and added together with $176 \mathrm{mg}$ dithiothreitol (DTT) (Sigma-Aldrich CAS nr. 3483-12-3) before adjusting the volume to $200 \mathrm{~mL}$. The OPA reagent was freshly made 
Table 1 Proximate composition of ground T. molitor and its protein fractions (mean $\pm \mathrm{SD}$, $n=2$ )

\begin{tabular}{llll}
\hline & Protein \% dry matter $(\mathrm{DM})$ & Fat \% DM & Protein \%DM after defatting \\
\hline T. molitor & $52.0 \pm 0.9$ & $30.8 \pm 0.9$ & $76.5 \pm 1.2$ \\
Supernatant & $56.7 \pm 0.8$ & - & $56.7 \pm 0.8$ \\
Pellet & $68.9 \pm 1.6$ & $14.5 \pm 0.4$ & $80.0 \pm 1.6$ \\
Residue & $69.1 \pm 1.6$ & $15.9 \pm 1.5$ & $83.1 \pm 1.1$ \\
\hline
\end{tabular}

Table 2 Identified muscle proteins of defatted and ground whole T. molitor, supernatant and pellet fractions (UniProt: taxonomy 50,557, Insecta)

\begin{tabular}{|c|c|c|c|c|c|c|}
\hline & Muscle proteins & $\begin{array}{l}\text { Main UniProt acces- } \\
\text { sion codes [1] }\end{array}$ & Mol. weight (kDa) & $\begin{array}{l}\text { Log } 10 \text { (iBAQ defat- } \\
\text { ted T. molitor) }\end{array}$ & Log 10 (iBAQ Pellet) & $\begin{array}{l}\text { Log } 10 \text { (iBAQ } \\
\text { supernatant) }\end{array}$ \\
\hline 1 & Alpha-actinin-4 & $\begin{array}{l}\text { P18091_DROME, } \\
\text { D2A2X1_TRICA; } \\
\text { E0VM19_PEDHC; }\end{array}$ & 107 & 5.7 & 5.8 & 5.9 \\
\hline 2 & Actin-like & $\begin{array}{l}\text { S5M0Y7_BOMMO; } \\
\text { T1DQP1_ANOAQ }\end{array}$ & 42 & 6.4 & 7.2 & 4.8 \\
\hline 3 & Tropomyosin 1 & $\begin{array}{l}\text { D6X4X2_TRICA; } \\
\text { Q1W295_9HEMI; } \\
\text { V5GNY3_ANOGL }\end{array}$ & 75.2 & 6.5 & 7.2 & 5.4 \\
\hline 4 & Tropomyosin 2 & $\begin{array}{l}\text { V5JDH8_NILLU; } \\
\text { B7ZGK8_9HEMI; } \\
\text { D6X4X3_TRICA }\end{array}$ & 32.5 & 6.9 & 8.2 & 5.5 \\
\hline 5 & Myosin heavy chain & V5G100_ANOGL & 262 & 5.8 & 6.8 & 3.5 \\
\hline 6 & $\begin{array}{l}\text { Myosin- } 2 \text { essential } \\
\text { light chain }\end{array}$ & E2BYA7_HARSA & 16.8 & & 5.3 & \\
\hline 7 & $\begin{array}{l}\text { Putative uncharacter- } \\
\text { ized protein (Myo- } \\
\text { sin_tail) }\end{array}$ & D6WI56_TRICA & 60.1 & 5.7 & 7.1 & 3.9 \\
\hline 8 & $\begin{array}{l}\text { Calcium-transporting } \\
\text { ATPase }\end{array}$ & V5GVT5_ANOGL & 72.9 & & 4.8 & \\
\hline 9 & Calponin & $\begin{array}{r}\text { Q1XFP4_ELACU; } \\
\text { D2A180_TRICA }\end{array}$ & 20.3 & 6.9 & 6.7 & 7.4 \\
\hline 10 & Putative troponin $\mathrm{C}$ & A2I491_MACHI & 18.4 & & 7.0 & \\
\hline 11 & Troponin 1 & C0M4Y2_NILLU & 23.8 & & 6.7 & \\
\hline 12 & Troponin $\mathrm{T}$ & D3TS62_GLOMM & 47.3 & 6.9 & 6.7 & 7.1 \\
\hline
\end{tabular}

Italicized values: putative uncharacterized proteins identified based on family and domain databases from UniProt. Mol. Weight $=$ molecular weight as calculated from the amino acid sequence

for every experiment. A calibration curve was made using L-leucine (Sigma-Aldrich, CAS nr. 61-90-5) ranging from 0.078 to $10 \mathrm{mM}$. Absorbance was measured at $340 \mathrm{~nm}$.

Protein digestion was quantified based on determining the amounts of free $\mathrm{NH}_{2}$ groups based on Schasteen et al. [11] with some modifications. The values for digestibility were expressed as the amounts of free $\mathrm{NH}_{2}$ groups digested from $1 \mathrm{mg}$ protein. Further, initial free $\mathrm{NH}_{2}$ groups, in which "initial" refers to the undigested sample, are presented separately within all figures. Digestibility values were expressed using Eq. 1. "Final" refers to the digested protein fractions, and "acid" to complete hydrolysis in $6 \mathrm{~N}$ $\mathrm{HCl}, 110^{\circ} \mathrm{C}$ for $24 \mathrm{~h}$.

Digestibility $=[$ Free NH2(final) $] /[$ Free NH2(acid) $]$

\section{Sodium dodecyl sulfate-polyacrylamide gel electrophoresis}

Sodium dodecyl sulfate-polyacrylamide gel electrophoresis (SDS-PAGE) was used to determine the molecular weight distribution of the insect protein fractions. Undigested and digested fractions were analyzed on $12 \%$ Bis/ Tris NuPAGE gels (Invitrogen, Carlsbad, USA) using MES running buffer under reducing conditions. The Mark $12^{\mathrm{TM}}$ Unstained Standard (2.5-200 kDa) (Invitrogen, Carlsbad, USA) was applied as a reference. The gels were then Coomassie-stained. A standard curve was made by measuring the migration distance of proteins with known molecular weight ( $\mathrm{Mw}$ standards). Unknown molecular weights were calculated using this standard curve. 


\section{Results}

\section{The proximate composition of protein fractions}

The proximate composition of $T$. molitor and its protein fractions with regard to lipid and protein content was determined on a dry matter basis (Table 1). The measured crude protein content was $52 \%$ in ground T. molitor, $57 \%$ in supernatant fraction, and $69 \%$ in both pellet/residue fractions. After defatting the whole T. molitor and its waterinsoluble fractions (pellet and residue), the measured protein content increased $24 \%$ in ground T. molitor, 11 and $14 \%$ in the pellet and the residue fraction, respectively. Furthermore, the lipid content of ground T. molitor was $31 \%$ on a dry matter basis. The lipid content of pellet was found to be $15 \%$, similar to that of residue. No lipid was found in supernatant fractions.

\section{Identification of proteins from the water-soluble and water-insoluble fractions of $\boldsymbol{T}$. molitor}

Proteins extracted as water-soluble fraction (supernatant) or as water-insoluble fraction (pellet) of T. molitor were identified by nano LC-MS/MS analysis (as shown in supplementary file 1). Tables 2 (muscle proteins found in the pellet) and 3 (most abundant non-muscle proteins) summarize the proteomics results. There were several types of muscle proteins including actin-like $(42 \mathrm{kDa})$, a-actinin-4 $(107 \mathrm{kDa})$, myosin heavy chain $(262 \mathrm{kDa})$, myosin-2 essential light chain $(16.8 \mathrm{kDa})$, tropomyosin $1(75.2 \mathrm{kDa})$ and 2 $(32.5 \mathrm{kDa})$, troponin I (23.8 kDa), troponin $\mathrm{T}(47.3 \mathrm{kDa})$, and putative troponin C (18.3 kDa) identified. Seven types of muscle proteins were not only observed in the pellet, but were also significantly present $(\log \mathrm{iBAQ}>3.5)$ in the supernatant fraction, including a-actinin-4 (107 kDa), tropomyosin 1 and 2, and calponin (20.3 $\mathrm{kDa})$.

The insecta database was also used to identify the most abundant proteins present in T. molitor based on iBAQ values (Table 3). The main proteins observed in supernatant were: hemolymph protein (a-e), alpha-amylase, two putative proteinases $(28.2$ and $27.6 \mathrm{kDa})$, and a stress related protein. Hemolymph proteins, desiccation stress protein, putative trypsin-like proteinase, and a putative serine proteinase were also abundantly observed in the pellet (Table 3).

In comparison with proteins identified in the supernatant fraction, muscle proteins like tropomyosin 1 and 2 and actin were more abundant in the pellet (more than 100fold). These muscle proteins were not identified as stemming from T. molitor (because they were absent from the database used), but from better characterized insects like Tribolium castaneum or Glossina morsitans morsitans. For the supernatant fraction, most proteins that were identified were from T. molitor. However, in the pellet fraction, several (non- $T$. molitor) putative uncharacterized proteins were found in a large quantity (iBAQ) among the identified proteins (Table 2). According to family and domain databases from UniProt, these putative uncharacterized proteins were highly homologue to actin/actin-like and tropomyosin (Supplementary file 2). This information indicates that muscle proteins were the most abundant proteins found in the pellet. As expected, for defatted and ground T. molitor, the same types of proteins were found as in the combination of supernatant and pellet fractions. Unfortunately, to date, the Insecta database is not complete, and therefore, proteins not present in the database will have escaped from being identified. Ten percent of the recorded MSMS spectra were identified when the Insecta database was used. This rather low percentage also indicates that the database is not complete. Also, due to use of an incomplete database, intensity values given in Table 2 may have been underestimated.

\section{Protein digestibility determination by OPA assay}

Using Eq. 1, protein digestibility of the ground T. molitor, supernatant, pellet, and residue fractions from gastricduodenal digestion was calculated. Protein digestibility of defatted and ground T. molitor increased from around 24 to $39 \%$ with increasing gastric digestion time (10-120 min) (Fig. 1a). Subsequently, after $2 \mathrm{~h}$ duodenal digestion, protein digestibility of all fractions obtained after gastric digestion increased to values ranging from 33 to $54 \%$. The initial amount of free $\mathrm{NH}_{2}$ group expressed as a percentage of total free $\mathrm{NH}_{2}$ was around $11 \%$ in defatted and ground T. molitor.

Protein digestibility of supernatant fractions was around $75 \%$ after gastric digestion and was nearly $85 \%$ after duodenal digestion (Fig. 1b). Increasing gastric digestion time from 10 to $120 \mathrm{~min}$ did not clearly increase protein digestibility of the supernatant fraction. The initial content of free $\mathrm{NH}_{2}$ groups expressed as a percentage of total free $\mathrm{NH}_{2}$ groups was found to be around $33 \%$.

Protein digestibility of the pellet fraction increased from 29 to $37 \%$ with increasing gastric digestion time (Fig. 1c). Subsequently, protein digestibility after duodenal digestion was around $45 \%$ for pellet. The initial content of the amount of free $\mathrm{NH}_{2}$ group as a percentage of total free $\mathrm{NH}_{2}$ groups was $12 \%$.

For the residue, protein digestibility increased from 13 to $23 \%$ with longer gastric digestion time (Fig. 1d). Duodenal digestion compared to gastric digestion alone increased digestibility values, except for $t=60 \mathrm{~min}$. The initial percentage of free $\mathrm{NH}_{2}$ groups in residue was $4 \%$. In comparison with water-soluble protein fractions (supernatant), proteins in pellet as well as in residue fractions 
Table 3 Most abundant non-muscle proteins [+: $\log 10$ (iBAQ) > 7] identified of defatted and ground the whole T. molitor, supernatant and pellet fractions (UniProt: taxonomy 50,557, Insecta) as determined by LC-MS/MS

\begin{tabular}{|c|c|c|c|c|c|c|c|}
\hline & $\begin{array}{l}\text { Most abundant } \\
\text { non-muscle } \\
\text { proteins }\end{array}$ & $\begin{array}{l}\text { UniProt accession } \\
\text { [1] }\end{array}$ & $\begin{array}{l}\text { Mol. weight } \\
(\mathrm{kDa})\end{array}$ & $\begin{array}{l}\text { Present in defatted } \\
\text { T. molitor }\end{array}$ & Present in pellet & $\begin{array}{l}\text { Present in } \\
\text { supernatant }\end{array}$ & $\begin{array}{l}\text { Family and domain } \\
\text { databases }\end{array}$ \\
\hline 1 & Alpha-amylase & P56634_TENMO & 51.2 & + & & + & \\
\hline 2 & $\begin{array}{l}\text { Putative trypsin- } \\
\text { like proteinase }\end{array}$ & $\begin{array}{l}\text { A1XG57_- } \\
\text { TENMO }\end{array}$ & 27.6 & & + & + & \\
\hline 3 & $\begin{array}{l}\text { Putative serine } \\
\text { proteinase }\end{array}$ & $\begin{array}{l}\text { A1XG83 } \\
\text { TENMO }\end{array}$ & 28.2 & & + & + & \\
\hline 4 & Histone H4 & H9K697_APIME & 21.2 & & + & & \\
\hline 5 & $\begin{array}{l}\text { Putative unchar- } \\
\text { acterized protein }\end{array}$ & D6W9T6_TRICA & 20.4 & & + & & $\begin{array}{l}\text { EF-hand domain } \\
\text { pair (including } \\
\text { troponin } C \text {, and } \\
\text { myosin essential } \\
\text { chain) }\end{array}$ \\
\hline 6 & $\begin{array}{l}\text { Putative unchar- } \\
\text { acterized protein }\end{array}$ & D6X095_TRICA & 16.9 & & + & & $\begin{array}{l}\text { EF-hand domain } \\
\text { pair (including } \\
\text { troponin } C \text {, and } \\
\text { myosin essential } \\
\text { chain) }\end{array}$ \\
\hline 7 & $\begin{array}{l}\text { 28-kDa desic- } \\
\text { cation stress } \\
\text { protein }\end{array}$ & Q27013_TENMO & 24.8 & + & + & + & \\
\hline 8 & $\begin{array}{l}\text { 13-kDa hemo- } \\
\text { lymph protein a }\end{array}$ & $\begin{array}{l}\text { Q7YWD2_- } \\
\text { TENMO }\end{array}$ & 13.2 & + & + & + & \\
\hline 9 & $\begin{array}{l}\text { 12-kDa hemo- } \\
\text { lymph protein e }\end{array}$ & $\begin{array}{c}\text { Q7YWD4_- } \\
\text { TENMO }\end{array}$ & 13.8 & & & + & \\
\hline 10 & $\begin{array}{l}\text { 12-kDa hemo- } \\
\text { lymph protein d }\end{array}$ & $\begin{array}{c}\text { Q7YWD5_ } \\
\text { TENMO }\end{array}$ & 13.9 & + & & + & \\
\hline 11 & $\begin{array}{l}\text { 12-kDa hemo- } \\
\text { lymph protein c }\end{array}$ & $\begin{array}{c}\text { Q7YWD6_ } \\
\text { TENMO }\end{array}$ & 14.0 & + & & + & \\
\hline 12 & $\begin{array}{l}\text { 12-kDa hemo- } \\
\text { lymph protein b }\end{array}$ & $\begin{array}{l}\text { Q7YWD7_- } \\
\text { TENMO }\end{array}$ & 14.1 & + & + & + & \\
\hline 13 & Hexamerin 2 & Q95PI7_TENMO & 84.5 & + & + & & \\
\hline 14 & $\begin{array}{l}86 \mathrm{kDa} \text { early- } \\
\text { staged encapsu- } \\
\text { lation-inducing } \\
\text { protein }\end{array}$ & $\begin{array}{l}\text { Q9Y1W5_ } \\
\text { TENMO }\end{array}$ & 90.6 & & + & & \\
\hline 15 & $\begin{array}{l}\text { 56-kDa early- } \\
\text { staged encapsu- } \\
\text { lation-inducing } \\
\text { protein }\end{array}$ & $\begin{array}{l}\text { Q9Y1W6_ } \\
\text { TENMO }\end{array}$ & 62.5 & & + & & \\
\hline
\end{tabular}

Italicized values: putative uncharacterized proteins identified based on family and domain databases from UniProt. Mol. Weight $=$ molecular weight as calculated from the amino acid sequence

showed relatively lower digestibility after gastric digestion and duodenal digestion.

\section{SDS-PAGE}

Reduced SDS-PAGE using $12 \%$ Bis/Tris gels (Fig. 2) showed the protein band patterns of ground $T$. molitor and its protein fractions (supernatant, pellet, and residue) after gastric digestion (incubating from 0 to $120 \mathrm{~min}$ ) and subsequently followed by duodenal digestion (incubating $120 \mathrm{~min}$ ).
For defatted and ground whole T. molitor, it is clear from the gels that the overall intensity as well as the band pattern changed upon digestion time (Fig. 2a, b). The major bands of the initial defatted ground whole T. molitor had $\mathrm{Mw}$ of 151, 124, 80, 30-50, 17, 12, and $10 \mathrm{kDa}$ (Fig. 2a). Protein bands with $\mathrm{Mw}$ of 124 and $151 \mathrm{kDa}$ were not observed after gastric digestion (10-120 min) (Fig. 2b). Instead, bands appeared in the range of $30-50 \mathrm{kDa}$, as well as protein bands at size of $<6 \mathrm{kDa}$. Furthermore, the bands ranging from 30 to $50 \mathrm{kDa}$ remained the same after duodenal 

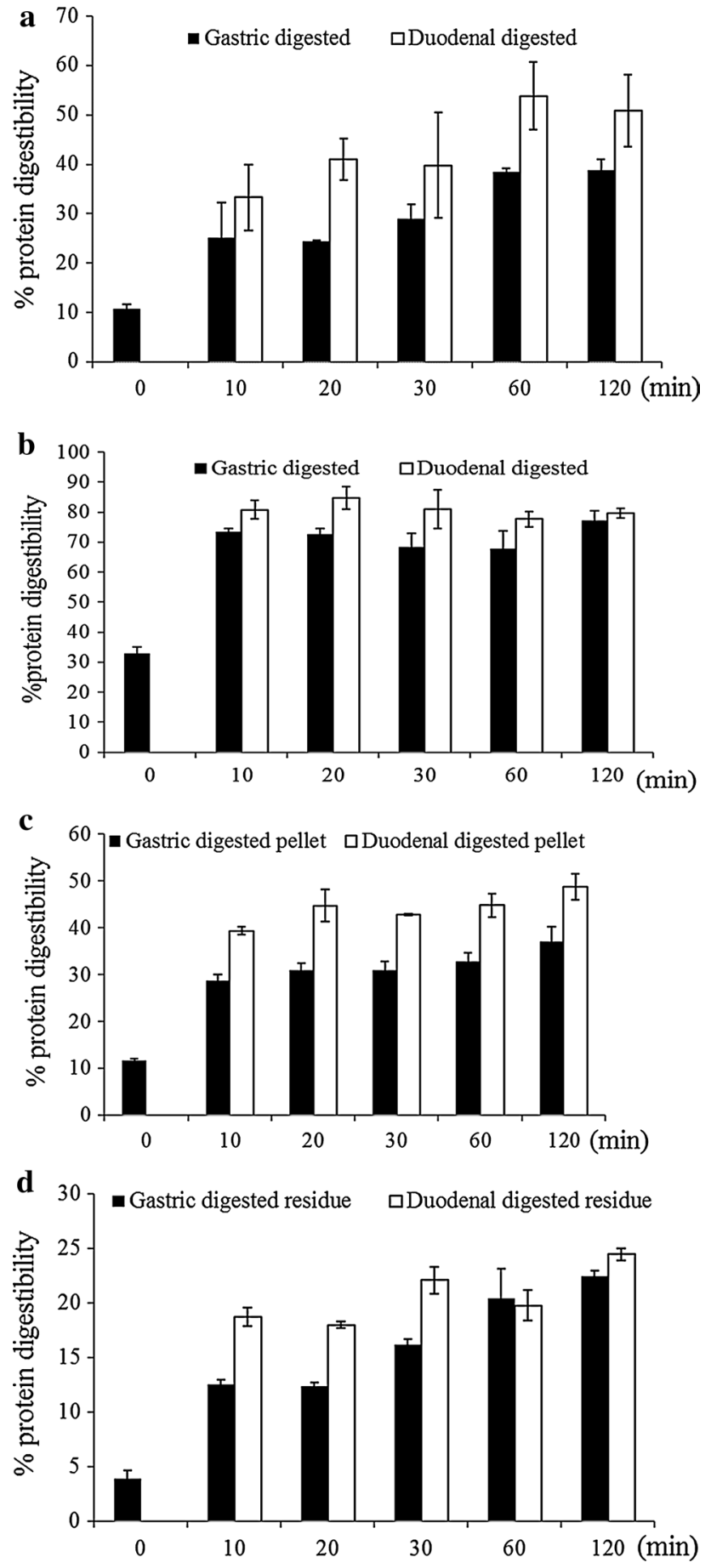

Fig. 1 Protein digestibility of the ground T. molitor and its protein fractions (expressed according to Eq. 1) after gastric digestion (incubating from 10 to $120 \mathrm{~min}$ ) followed by duodenal digestion (incubating $120 \mathrm{~min}$ ) (mean $\pm \mathrm{SD}, n=2$ ). a T. molitor, b supernatant, $\mathbf{c}$ pellet, $\mathbf{d}$ residue

digestion. Next to that, a band at around $80 \mathrm{kDa}$ became less intense upon increasing gastric digestion time and was completely absent after duodenal digestion. The protein band at around $12 \mathrm{kDa}$ did not disappear after both gastric and duodenal digestion.

Band patterns of the supernatant fraction were in a range of $<97 \mathrm{kDa}$, and prominent bands distributed at around 58, 45, 40, 30, 19, 13 and $8 \mathrm{kDa}$ (Fig. 2c). Protein bands at around $13,30,40$, and $45 \mathrm{kDa}$ remained not only after gastric digestion, but also after duodenal digestion (Fig. 2d). The intensity of two bands decreased. A band at $58 \mathrm{kDa}$ was absent after gastric-duodenal digestion. A single protein band at $8 \mathrm{kDa}$ disappeared, instead "smear" bands smaller than $6 \mathrm{kDa}$ appeared, especially after the first 10 min of gastric digestion.

In the initial pellet fraction, the major proteins were visible at $75,46,36,30,24,23,19,17$, and $13 \mathrm{kDa}$ and bands of $<6 \mathrm{kDa}$ (Fig. 2e). The intensity of the initial pellet fraction was lower than that extracted after gastric-duodenal digestion, due to its poor solubility during sample preparation. The intensity of a band at $75 \mathrm{kDa}$ was slowly decreasing with increasing gastric digestion time (Fig. 2f). The pattern and intensity of bands ranging from $30 \mathrm{kDa}$ to $50 \mathrm{kDa}$ remained largely the same after gastric-duodenal digestion, which was similar to the trend in defatted ground whole T. molitor.

The water-insoluble residue protein fraction was also investigated in terms of molecular weight distribution. However, the initial residue was not visible when applying on the SDS-PAGE gels, due to its poor solubility in water. Therefore, the protein pattern of residue extracted after gastric-duodenal digestion was present without the initial protein bands in residue (Fig. $2 \mathrm{~g}$ ). The protein bands were found at round $95-80,70,49,39,29,19,13$, and $<6 \mathrm{kDa}$ after the first $10 \mathrm{~min}$ gastric digestion. Most of the major bands were visible over the range of $70,49,39,29,13$, and strong "smear" bands $<6 \mathrm{kDa}$ upon increasing digestion. However, several bands at 95-80 kDa were less intense with increasing gastric digestion time and subsequently disappeared after duodenal digestion.

\section{Discussion}

\section{Protein content determined by total nitrogen versus amino acid content}

Protein content of T. molitor was determined by total nitrogen content (Dumas) multiplied by a protein factor of 6.25 . However, Hall and Schönfeldt [24] stated that the protein content as determined by total nitrogen is not accurate due to chemical and compositional differences between proteins, as well as the presence of non-protein nitrogen. Lysine, tryptophan, histidine, and arginine contain additional nitrogen atoms in comparison with other amino 


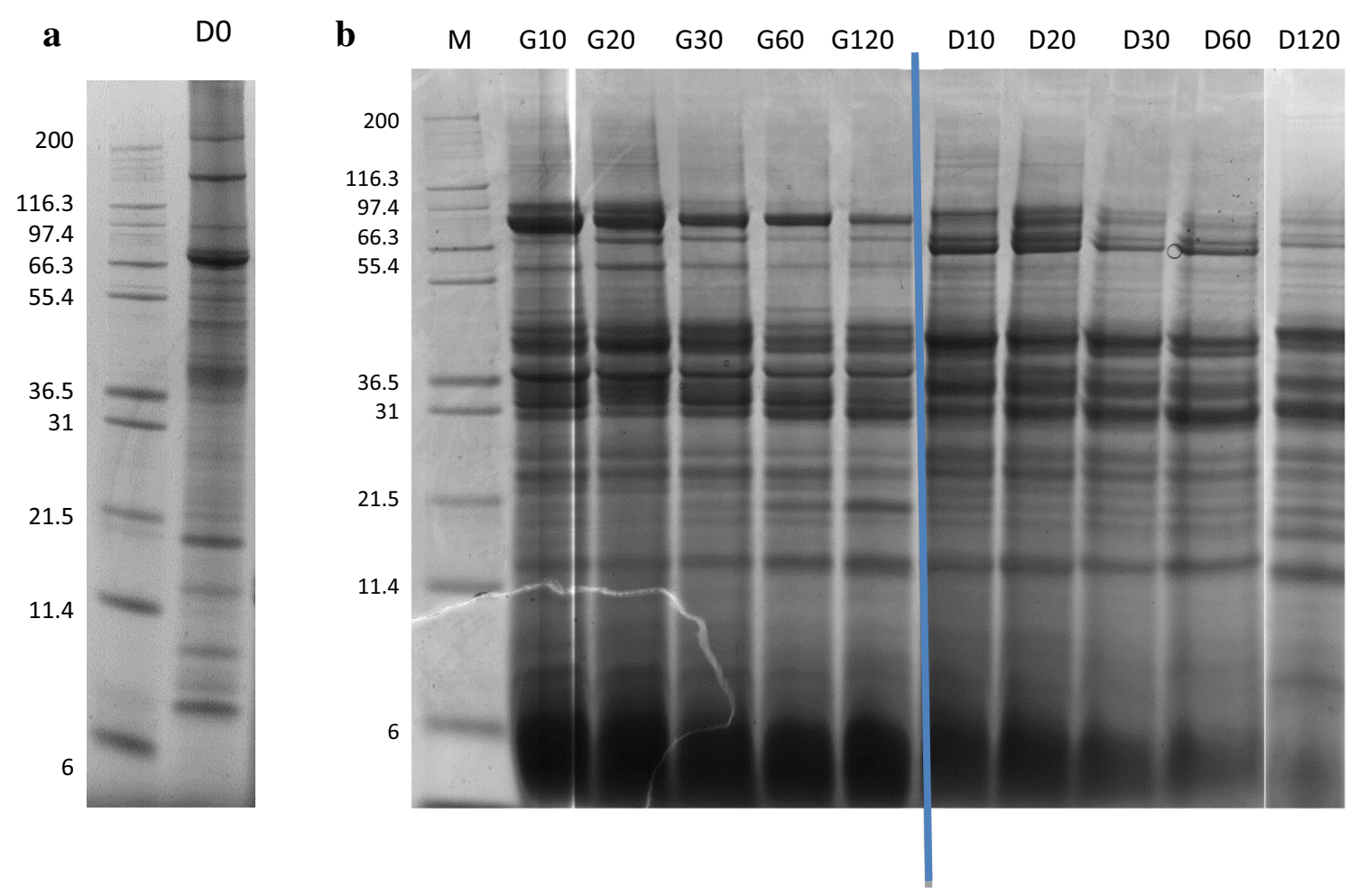

Defatted T. molitor (A and B)
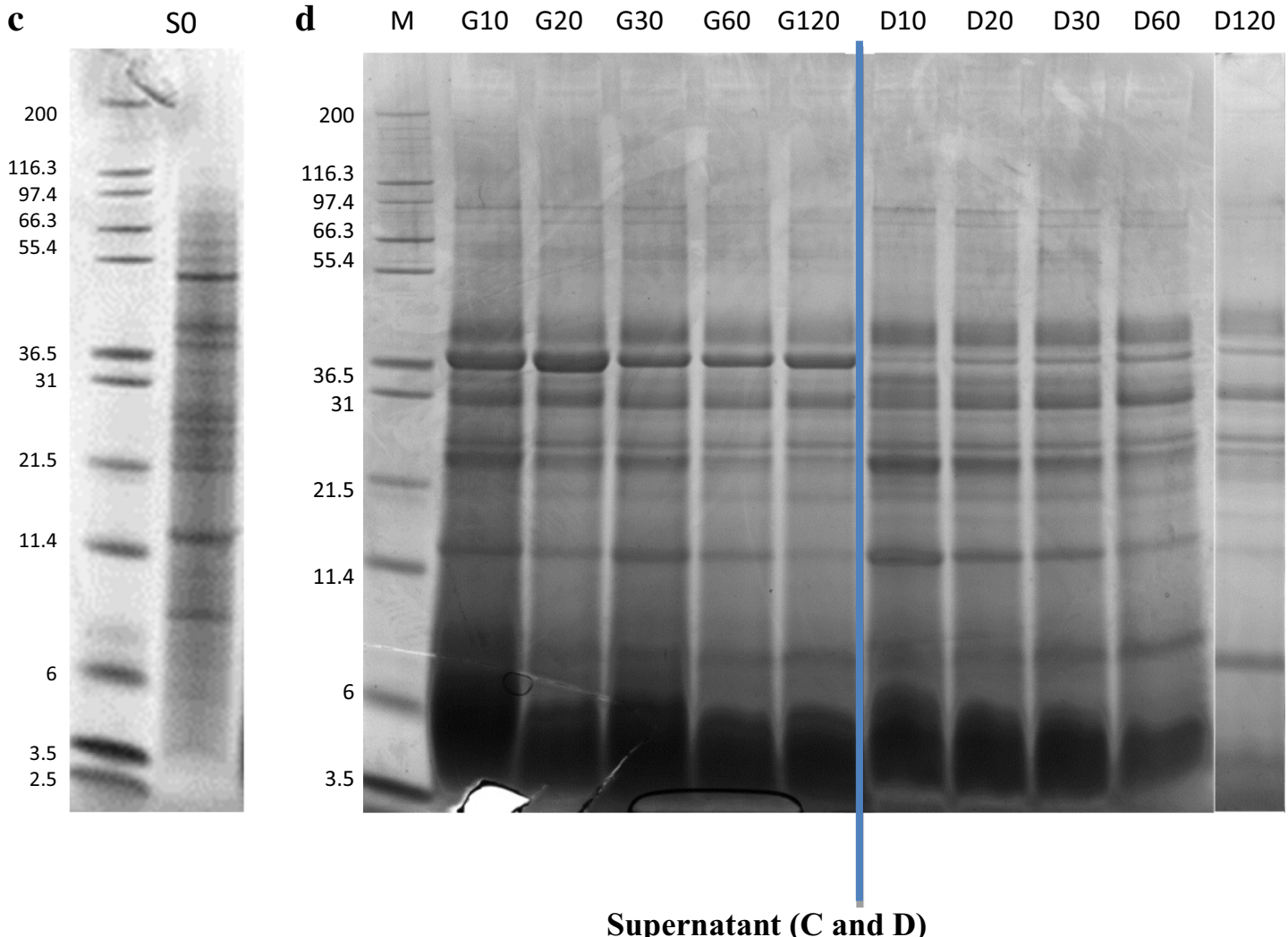

Fig. 2 Band patterns of the ground T. molitor and its protein fractions after gastric digestion (incubating from 10 to $120 \mathrm{~min}$ ) and subsequent duodenal digestion (incubating $120 \mathrm{~min}$ ) as determined by reduced SDS-PAGE 


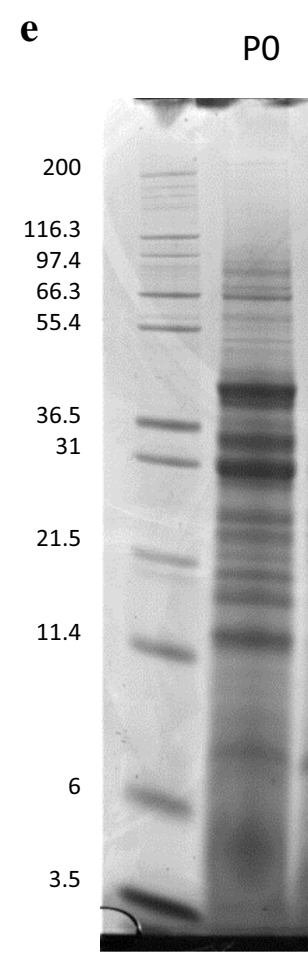

f
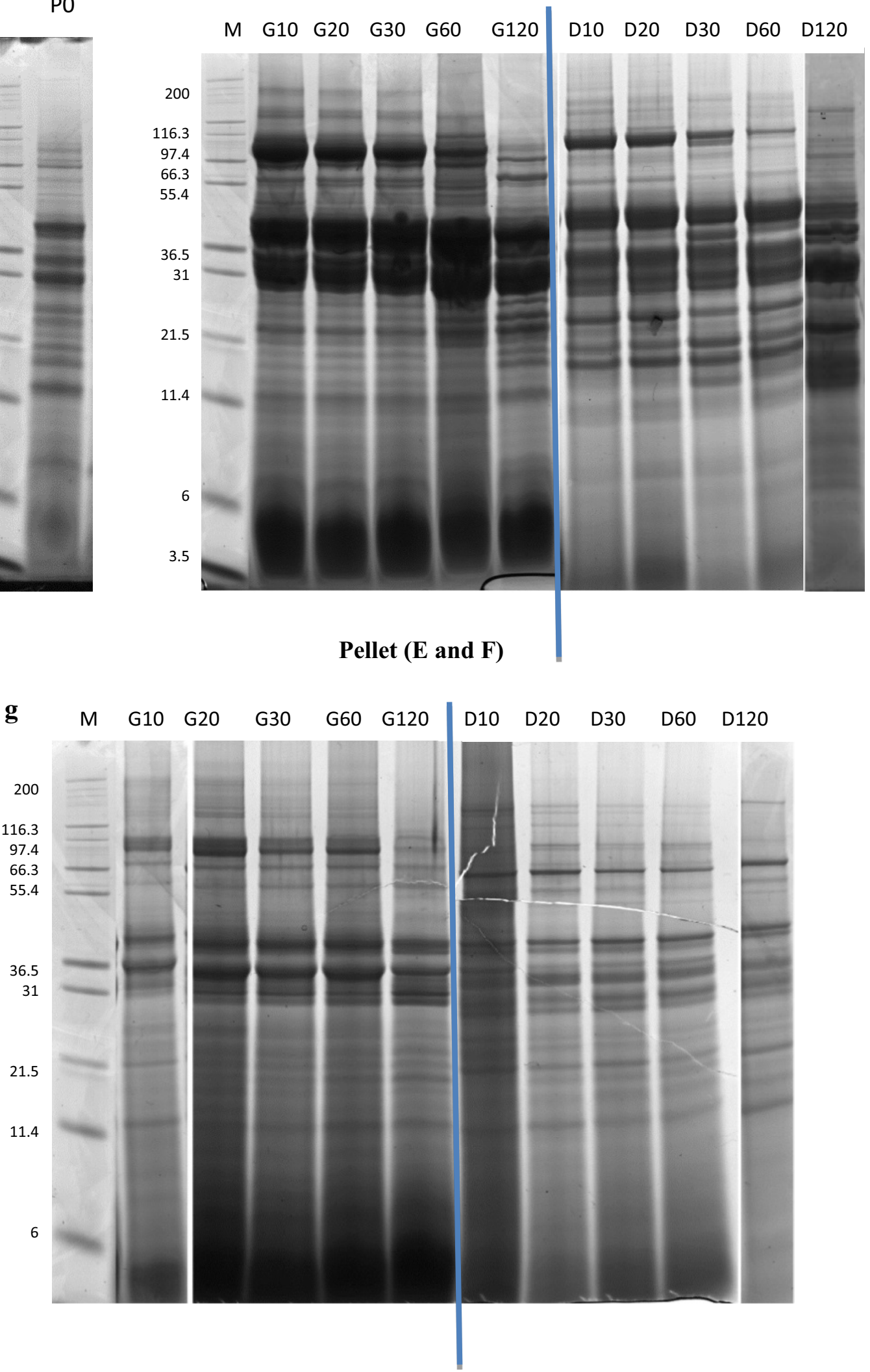

\section{Residue (G)}

Fig. 2 continued 
acids. It means that if T. molitor contains large amounts of these high nitrogen-containing amino acids, the amount of nitrogen analyzed would result in inaccurate protein content. In our previous study of Yi et al. [4], the total amount of amino acids found in defatted and ground T. molitor was $910 \mathrm{mg} / \mathrm{g}$ protein, and such value did not end up to $1000 \mathrm{mg} / \mathrm{g}$ protein which could be explained by the presence of non-protein nitrogen. Besides, concentrating on the influence of side-chain differences between amino acids, the sum of total amount of amino group nitrogen could be calculated by using the amount of each amino acid divided by molecular weight of each amino acid and then multiplied by molecular weight of nitrogen. Using the data of Yi et al. [4], the rough sum of total amount of amino group nitrogen in defatted and ground whole T. molitor is calculated to be $128 \mathrm{mg} / \mathrm{g}$ crude protein extract. However, a precise value for a protein factor could not be given due to the presence of non-protein nitrogen, uncertainties in ash content, and occurence of free amino acids as reported for other protein sources $[25,26]$.

\section{Protein digestibility by OPA essay and SDS-PAGE}

Protein fractions of T. molitor were digested more after the in vitro duodenal process than after the in vitro gastric process (Fig. 1), which is qualitatively confirmed by the intensity of protein bands of SDS-PAGE, except for the supernatant fraction. Furthermore, strong intense protein bands $<6 \mathrm{kDa}$ appeared in most fractions, which explains the increase of free $\mathrm{NH}_{2}$ groups after gastric-duodenal digestion. Next to that, the initial content of free $\mathrm{NH}_{2}$ in supernatant showed a very high value of $33 \%$ in comparison with the pellet and residue as determined by OPA essay.

The specific digestibility of soluble versus insoluble proteins by in vitro method has not been reported for T. molitor before. However, studies on in vitro digestion of other animal sources that are used as a whole for fish feed (i.e., fish larvae and cod filet) have been reported by Tonheim et al. [27]. These authors measured nitrogen content of the TCAsoluble nitrogen in order to determine protein digestibility. Alike our results, proteins of water-soluble fraction of the live feeds (Artemia and Calanus) were more digestible than those of water-insoluble fraction. Similar to our data, the initial TCA-nitrogen content of water-soluble fraction in Artemia was found to be around $38 \%$, which can be explained by proteolysis. Goptar et al. [28] and Verhoeckx et al. [15] mentioned that the major digestive peptidases of T. molitor are cysteine peptidases (mainly cathepsin L) and serine peptidases (including four trypsin-like and five chymotrypsin-like serine peptidases), as well as membranebound amino-peptidase present in the midgut. According to Bishop [29], protein autolysis could indeed occur in insect body, as was shown for bee larvae. This autolysis occurred due to the degradation of muscle or skin protein by endogenous enzymes [30]. In addition, Tonheim et al. [27] mentioned that autolysis could occur, even though extraction took place at low temperature. This could explain the high initial content of free $\mathrm{NH}_{2}$ groups found in supernatant of T. molitor.

\section{Protein identification by LC-MS/MS, SDS-PAGE, and digestion}

\section{Muscle proteins}

Myofibrils, the most abundant protein in muscular tissue, mainly consist of myosin heavy chain/light chain ( 43\%), actin $(\sim 20 \%)$, and other minor proteins such as, tropomyosin $(\sim 5 \%)$, troponins $(\sim 5 \%)$, and $\alpha$-actinin $(\sim 2 \%)$ [31, 32]. Myosin heavy chain and light chains from sardines (Sardinella longiceps) showed molecular weights of 205, 31,23 , and $22 \mathrm{kDa}$ [33]; myosin from white mackerel muscle had three light chain subunits with $\mathrm{Mw}$ of 26.5, 20, and $17.5 \mathrm{kDa}$ [34]. Furthermore, Mw of light chains of carp ranged between 16 and $26 \mathrm{kDa}$ [35]. The exact molecular weights of myosin vary among species. Corresponding to myofibril proteins found in T. molitor, myosin heavy chain had a molecular weight of $262.3 \mathrm{kDa}$, and myosin light chain of $16.8 \mathrm{kDa}$, as is shown in Table 2. Further, based on the data, myosin heavy chain was presented but not quantified as a major protein in pellet fractions in Table 2.

\section{Identification and digestion of proteins in pellet fraction}

Muscle proteins (especially myofibrillar protein) are classified as salt-soluble or salt-insoluble fractions [32]. From the LC-MS/MS results (Tables 2, 3), proteins were identified in the water-insoluble protein fraction (pellet), including actin, a-actinin-4 (107 kDa), myosin heavy chain $(262 \mathrm{kDa})$, myosin-2 essential light chain $(16.8 \mathrm{kDa})$, tropomyosin $2(32.5 \mathrm{kDa})$, troponin $\mathrm{I}(23.8 \mathrm{kDa})$, troponin $\mathrm{T}(47.3 \mathrm{kDa})$, and putative troponin $\mathrm{C}(18.3 \mathrm{kDa})$. Using intensity-based absolute quantification (iBAQ) data as quantitative data, those proteins were found in high amount in pellet fraction, in comparison with those in supernatant or defatted and ground whole T. molitor. Those larger amounts of muscle proteins in pellet fraction (especially actin and tropomyosin 2) were distributed from 30 to $50 \mathrm{kDa}$ as determined by LC-MS/MS, corresponding to the strong intensity of bands between 30 and $50 \mathrm{kDa}$ in pellet as determined by SDS-PAGE. In addition, those bands in pellet $(30-50 \mathrm{kDa})$ showed less intensity after duodenal digestion than after gastric digestion. Furthermore, these muscle proteins $(30-50 \mathrm{kDa})$ could be gradually digested with increasing digestion time as observed by OPA results, but this was not clearly confirmed by SDS-PAGE. Similar 
results were found by Santé-Lhoutellier et al. [36] for muscle protein $(30-50 \mathrm{kDa})$ in lamb, and actin $(\sim 50 \mathrm{kDa})$, troponin $\mathrm{T}$ ( $\sim 4 \mathrm{kDa})$, and tropomyosin $(\sim 40 \mathrm{kDa})$ were determined by SDS-PAGE.

In our study, among all muscle proteins identified, protein tropomyosin was found as one of the most abundant proteins in pellet (LC-MS/MS). Liu et al. [31] and Verhoeckx et al. [15] mentioned tropomyosin not only as part of myofibrillar protein, but also as the major allergen in fish, shrimp, and crab. Furthermore, tropomyosin in pacific white shrimp, as well as in grass prawn was hardly degraded by pepsin (in vitro gastric digestion) (from $t=0$ to $t=60 \mathrm{~min}$ ), but gradually degraded by trypsin and $\alpha$-chymotrypsin (in vitro duodenal digestion) (from $t=0$ to $t=240 \mathrm{~min}$ ) as determined by SDS-PAGE [31]. These findings are in line with the band patterns found at around $35 \mathrm{kDa}$ in pellet fraction of T. molitor based on SDS-PAGE (Fig. 2f). It showed that proteins at around $35 \mathrm{kDa}$ in pellet fractions were likely not degraded with time increasing in gastric digestion, but still visible after duodenal digestion.

Next to that, actin $(\sim 42 \mathrm{kDa})$ in pacific white shrimp was found to be gradually digested by pepsin, as well as by trypsin $(t=120 \mathrm{~min})$, and completely digested by $\alpha$-chymotrypsin $(t=120 \mathrm{~min})$. However, according to our SDS-PAGE results, the intensity of bands $(30-40 \mathrm{kDa})$ identified as actin in pellet fraction (Fig. 2f) was also reduced after duodenal digestion in comparison with that after gastric digestion, but not completely digested $(t=120 \mathrm{~min})$. The different protein band pattern could be explained by different positions at which amino acids are cleaved in vitro by trypsin and chymotrypsin. It is known that pepsin splits proteins to smaller parts which increases its accessibility, but does not digest proteins to amino acids [5]; trypsin cleaves peptide bonds on the carboxyl side of arginine or lysine, and chymotrypsin usually cleaves peptide bonds on the carboxyl side of aromatic amino acids (phenylalanine, tryptophan and tyrosine) or leucine [37, 38].

In comparison with myofibrillar proteins from other meat sources, Storcksdieck et al. [39] reported that digestion of myofibrillar protein extracted from fresh beef, chicken, lamb, and pork, or frozen cod fillets resulted in high amounts of low molecular weight peptides $<10 \mathrm{kDa}$. That was based on centrifugation and ultrafiltration through $10-\mathrm{kDa}$ molecular weight cut-off membranes after using pepsin, as well as after using pepsin/pancreatin. The amounts of molecular weight peptides $>10 \mathrm{kDa}$ were found in beef, chicken, cod, lamb, and pork after pepsin only or pepsin/pancreatin digestion based on the change of nitrogen content [39]. Furthermore, the nitrogen content of all meat extracts ranged from 55 to $65 \%$ of total nitrogen after using pepsin only, which was slightly lower than the range from 66 to $79 \%$ observed after using pepsin/pancreatin as determined by the Kjeldahl method $(N \times 6.25)$. In our study, the values for protein digestibility found in pellet ranged from 29 to $37 \%$ by using pepsin only and were around $45 \%$ by using pepsin/pancreatin, which is relatively low in comparison with meat extracts as mentioned above. Alike our results, a strong "smear" group $<6 \mathrm{kDa}$ was also observed in the pellet after pepsin digestion. However, this group of bands remained the same for pepsin and pepsin/pancreatin digestion, and showed less intense bands by using pepsin/pancreatin (Fig. 2f). Regarding the myofibrillar proteins in pellet of T. molitor, the major bands remained often the same for in vitro gastric-duodenal digestion, although less intense bands were found after duodenal digestion.

\section{Identification and digestion of proteins in supernatant fraction}

In supernatant (water-soluble protein fraction) after gastric-duodenal digestion, major bands were found at 13, $19,30,40$, and $45 \mathrm{kDa}$ by using SDS-PAGE, likely corresponding to hemolymph protein $(\sim 13 \mathrm{kDa})$, putative serine proteinase $(\sim 28 \mathrm{kDa})$, and alpha-amylase $(\sim 50 \mathrm{kDa})$ identified by LC-MS/MS. The band at $13 \mathrm{kDa}$ (hemolymph protein $\sim 13 \mathrm{kDa}$ ) was digested with increasing digestion time $(t=120 \mathrm{~min})$ after in vitro gastric digestion. In vitro duodenal digestion did not seem to add substantially to digestion of this protein. Beside this band, the bands ranging from 20 to $50 \mathrm{kDa}$ show a completely different pattern after duodenal digestion than after gastric digestion. Furthermore, in comparison with the initial protein pattern of supernatant, bands with molecular weight $>50 \mathrm{kDa}$ were hardly observed after gastric digestion or duodenal digestion. Proteins at molecular sizes $>50 \mathrm{kDa}$ apparently could be digested easily by pepsin $(t=10 \mathrm{~min})$. Those water-soluble proteins consist of sarcoplasmic proteins as a major portion of muscle proteins which consist of glycolytic enzymes, myoglobin, and other proteins present in intracellular fluid of muscle [40]. As mentioned by Verhoeckx et al. [15], sarcoplasmic Ca-binding proteins in watersoluble fraction of T. molitor were found at a molecular weight of $109.9 \mathrm{kDa}$. Storcksdieck et al. [39] mentioned that sarcoplasmic proteins are easily digested in comparison with myofibrillar protein, e.g., nitrogen content after digestion was $67 \%$ for chicken, $89 \%$ for beef, $88 \%$ for lamb, and $87 \%$ for pork of total nitrogen after pepsin/pancreatin digestion. It likely contributed to high digestibility of water-soluble protein fraction.

In addition, Verhoeckx et al. [15] reported that putative allergens found in water-soluble protein extracted from T. molitor contained cationic trypsin $(26.5 \mathrm{kDa})$, arginine kinase $(40.1 \mathrm{kDa})$ and tubulin $\alpha-1$ chain $(50.6 \mathrm{kDa})$, alpha-amylase (51.7 kDa), and ovalbumin-like (43.2 kDa) 
as determined by LC-MS/MS based on database homology with metazoan proteins. In our study, these putative allergic proteins could be found in both supernatant and pellet fraction though more abundant in supernatant fraction. Direct comparisons of protein digestibility between insect proteins and other proteins are difficult because many factors such as composition of the digestive fluids used in each step and types of enzyme or enzyme concentrations have impact on determining absolute digestibility values as reviewed by Hur et al. [41].

\section{Proteins in residue fraction}

Next to supernatant and pellet fractions, the band patterns of the residue were similar to the pellet, but the intensity of those bands was lower after duodenal digestion according to SDS-PAGE. The initial protein band in residue was not found in either LC-MS/MS or SDS-PAGE, due to its poor solubility during sample preparation.

\section{Conclusions}

This study produced data on protein digestibility of defatted and ground whole T. molitor and its water-soluble protein fraction (supernatant) and water-insoluble protein fractions (pellet and residue) after in vitro gastric-duodenal digestion.

With respect to protein identification and relative quantification as determined by LC-MS/MS, the most abundant proteins identified in supernatant were hemolymph protein and the putative allergen alpha-amylase, which correlated to the band patterns (12 and $50 \mathrm{kDa}$ ) based on SDS-PAGE. For the pellet fraction, the most abundant proteins were muscle proteins, including actin, tropomyosin, and troponin $\mathrm{T}$, mainly ranging from 30 to $50 \mathrm{kDa}$, corresponding to the strong intensity of bands $(30-50 \mathrm{kDa})$ based on SDS-PAGE. These proteins could be degraded more after duodenal digestion than after gastric digestion.

The digestibility of the water-soluble protein fraction (supernatant, about $80 \%$ ) was higher than that of waterinsoluble protein fraction (pellet $50 \%$ and residue $24 \%$ ) after in vitro gastroduodenal digestion as determined by the OPA essay. High amounts of free $\mathrm{NH}_{2}$ groups in supernatant (around $33 \%$ ) were found before digestion, which is likely due to autolysis. Furthermore, increasing digestion time had no clear impact on protein digestibility of supernatant and impact on protein digestibility of pellet and residue. These findings suggest that the water-soluble protein fraction was more easily digested than water-insoluble protein fraction found for gastric and duodenal digestion. This study gives insight into the bulk protein composition of $T$. molitor and the in vitro digestibility, thereby contributing to knowledge needed for future food applications of this insect species. Overall, we conclude that a major gap in knowledge is filled concerning protein composition of an insect like T. molitor and its digestibility. The findings are helpful in addressing the question whether or not insect proteins are a promising new source of food proteins.

Acknowledgments We would like to thank the Dutch Ministry of Economic Affairs for financially supporting this work as part of the SUPRO2 project (Sustainable production of insect proteins for human consumption). The authors thank Arnold van Huis for critically reading the manuscript. The authors also thank Marianne de Goeij for carrying out insect protein digestibility.

\section{Compliance with ethical standards}

Conflict of interest The authors declare that they have no conflict of interest.

Compliance with ethics requirements This article does not contain any studies with human or animal subjects.

Open Access This article is distributed under the terms of the Creative Commons Attribution 4.0 International License (http://creativecommons.org/licenses/by/4.0/), which permits unrestricted use, distribution, and reproduction in any medium, provided you give appropriate credit to the original author(s) and the source, provide a link to the Creative Commons license, and indicate if changes were made.

\section{References}

1. Ghaly AE, Alkoaik FN (2009) The yellow mealworm as a novel source of protein. Am J Agric Biol Sci 4(4):319-331

2. Finke M, Winn D (2004) Insects and related arthropods: a nutritional primer for rehabilitators. J Wildl Rehabil 27(3/4):14

3. Ghaly AE (2009) The black cutworm as a potential human food. Am J Biochem Biotechnol 5(4):210-220

4. Yi L, Lakemond CMM, Sagis LMC, Eisner-Schadler V, van Huis A, van Boekel MAJS (2013) Extraction and characterisation of protein fractions from five insect species. Food Chem 141(4):3341-3348

5. Akimov M, Bezuglov V (2012) Methods of protein digestive stability assay-state of the art. In: Brzozowski T (ed) New advances in the basic and clinical gastroenterology. InTech. ISBN: 978953-51-0521-3. doi:10.5772/33286

6. Wickham M, Faulks R, Mills C (2009) In vitro digestion methods for assessing the effect of food structure on allergen breakdown. Mol Nutr Food Res 53(8):952-958

7. Butts CA, Monro JA, Moughan PJ (2012) In vitro determination of dietary protein and amino acid digestibility for humans. Br J Nutr 108(Suppl 2):S282-S287

8. Rutherfurd SM (2010) Methodology for determining degree of hydrolysis of proteins in hydrolysates: a review. J AOAC Int 93(5):1515-1522

9. Spellman D, McEvoy E, O'Cuinn G, FitzGerald RJ (2003) Proteinase and exopeptidase hydrolysis of whey protein: comparison of the TNBS, OPA and pH stat methods for quantification of degree of hydrolysis. Int Dairy J 13(6):447-453

10. Nielsen PM, Petersen D, Dambmann C (2001) Improved method for determining food protein degree of hydrolysis. J Food Sci 66(5):642-646 
11. Schasteen CS, Wu J, Schulz MG, Parsons CM (2007) Correlation of an immobilized digestive enzyme assay with poultry true amino acid digestibility for soybean meal. Poult Sci 86(2):343-348

12. Longvah T, Mangthya K, Ramulu P (2011) Nutrient composition and protein quality evaluation of eri silkworm (Samia ricinii) prepupae and pupae. Food Chem 128(2):400-403

13. Kinyuru J, Kenji G, Njoroge S, Ayieko M (2010) Effect of processing methods on the in vitro protein digestibility and vitamin content of edible winged termite (Macrotermes subhylanus) and grasshopper (Ruspolia differens). Food Bioprocess Technol 3(5):778-782

14. Ramos-Elorduy J, Moreno JMP, Prado EE, Perez MA, Otero JL, de Guevara OL (1997) Nutritional value of edible insects from the state of Oaxaca, Mexico. J Food Compos Anal 10(2):142-157

15. Verhoeckx KCM, van Broekhoven S, den Hartog-Jager CF, Gaspari M, de Jong GAH, Wichers HJ, van Hoffen E, Houben GF, Knulst AC (2014) House dust mite (Der p 10) and crustacean allergic patients may react to food containing Yellow mealworm proteins. Food Chem Toxicol 65:364-373

16. Delahunty C, Yates Iii JR (2005) Protein identification using 2D-LC-MS/MS. Methods 35(3):248-255

17. Lu J, Boeren S, de Vries SC, van Valenberg HJF, Vervoort J, Hettinga K (2011) Filter-aided sample preparation with dimethyl labeling to identify and quantify milk fat globule membrane proteins. J Proteom 75(1):34-43

18. Wisniewski JR, Zougman A, Nagaraj N, Mann M (2009) Universal sample preparation method for proteome analysis. Nat Method 6(5):359-362

19. Cox J, Mann M (2008) MaxQuant enables high peptide identification rates, individualized p.p.b.-range mass accuracies and proteome-wide protein quantification. Nat Biotechnol 26(12):1367-1372

20. Cox JR, Neuhauser N, Michalski A, Scheltema RA, Olsen JV, Mann M (2011) Andromeda: a peptide search engine integrated into the MaxQuant environment. J Proteome Res 10(4):1794-1805

21. Smaczniak C, Li N, Boeren S, America T, van Dongen W, Goerdayal SS, de Vries S, Angenent GC, Kaufmann K (2012) Proteomics-based identification of low-abundance signaling and regulatory protein complexes in native plant tissues. Nat Protoc 7(12):2144-2158

22. Schwanhausser B, Busse D, Li N, Dittmar G, Schuchhardt J, Wolf J, Chen W, Selbach M (2011) Global quantification of mammalian gene expression control. Nature 473(7347):337-342

23. Vreeburg RAM, van Wezel EE, Ocaña-Calahorro F, Mes JJ (2012) Apple extract induces increased epithelial resistance and claudin 4 expression in Caco- 2 cells. J Sci Food Agric 92(2):439-444

24. Hall NG, Schönfeldt HC (2013) Total nitrogen vs. aminoacid profile as indicator of protein content of beef. Food Chem 140(3):608-612

25. Karman A, Van Boekel M (1986) Evaluation of the Kjeldahl factor for conversion of the nitrogen content of milk and milk products to protein content. Neth Milk Dairy J 40:315-316
26. Lourenço SO, Barbarino E, De-Paula JC, Pereira LODS, Marquez UML (2002) Amino acid composition, protein content and calculation of nitrogen-to-protein conversion factors for 19 tropical seaweeds. Phycol Res 50(3):233-241

27. Tonheim SK, Nordgreen A, Høgøy I, Hamre K, Rønnestad I (2007) In vitro digestibility of water-soluble and water-insoluble protein fractions of some common fish larval feeds and feed ingredients. Aquaculture 262(2-4):426-435

28. Goptar IA, Shagin DA, Shagina IA, Mudrik ES, Smirnova YA, Zhuzhikov DP, Belozersky MA, Dunaevsky YE, Oppert B, Filippova IY, Elpidina EN (2013) A digestive prolyl carboxypeptidase in Tenebrio molitor larvae. Insect Biochem Mol Biol 43(6):501-509

29. Bishop GH (1923) Autolysis and insect metamorphosis. J Biol Chem 58(2):567-582

30. Mukundan MK, Antony PD, Nair MR (1986) A review on autolysis in fish. Fish Res 4(3-4):259-269

31. Liu G-M, Huang Y-Y, Cai Q-F, Weng W-Y, Su W-J, Cao M-J (2011) Comparative study of in vitro digestibility of major allergen, tropomyosin and other proteins between Grass prawn (Penaeus monodon) and Pacific white shrimp (Litopenaeus vannamei). J Sci Food Agric 91(1):163-170

32. Marion LG (2008) Proteins. In: Leo ML, Toldrá NF (eds) Handbook of muscle foods analysis. CRC Press, Boca Raton, FL, pp $57-73$

33. Mathew S, Prakash V (2006) Effect of calcium salts on the properties of proteins from oil sardine (Sardinella longiceps) during frozen storage. J Food Sci 71(4):E178-E183

34. Watabe S, Hashimoto K (1980) Myosins from white and dark muscles of mackerel some physico-chemical and enzymatic properties. J Biochem 87(5):1491-1499

35. Okagaki T, Takami M, Hosokawa K, Yano M, Higashi-Fujime S, Ooi A (2005) Biochemical properties of ordinary and dark muscle myosin from carp skeletal muscle. J Biochem 138(3):255-262

36. Santé-Lhoutellier V, Engel E, Aubry L, Gatellier P (2008) Effect of animal (lamb) diet and meat storage on myofibrillar protein oxidation and in vitro digestibility. Meat Sci 79(4):777-783

37. Olsen JV, Ong S-E, Mann M (2004) Trypsin cleaves exclusively C-terminal to arginine and lysine residues. Mol Cell Proteomics 3(6):608-614

38. Swanson TA, Kim SI, Glucksman MJ, Lieberman MA (2010) BRS biochemistry, molecular biology, and genetics. Lippincott Williams \& Wilkins, Philadelphia

39. Storcksdieck S, Bonsmann G, Hurrell RF (2007) Iron-binding properties, amino acid composition, and structure of muscle tissue peptides from in vitro digestion of different meat sources. $\mathrm{J}$ Food Sci 72(1):S019-S029

40. Jesslin G, Sabaridasan A, Edwinthangam P, Palanikani R, Soranam R (2013) Electrophoretic studies on the muscle proteins of three species of genus Puntius (Osteichthyes-Cyprinidae). Int J Res Fish Aquac 3(2):16-20

41. Hur SJ, Lim BO, Decker EA, McClements DJ (2011) In vitro human digestion models for food applications. Food Chem 125(1):1-12 